\title{
Poly(ester amide)-Poly(ethylene oxide) Graft Copolymers: Towards Micellar Drug Delivery Vehicles
}

\author{
Gregory J. Zilinskas, ${ }^{1}$ Abdolrasoul Soleimani, ${ }^{2}$ and Elizabeth R. Gillies ${ }^{2,3}$ \\ ${ }^{1}$ Biomedical Engineering Graduate Program, The University of Western Ontario, 1151 Richmond Street, London, \\ ON, Canada N6A $5 B 7$ \\ ${ }^{2}$ Department of Chemical and Biochemical Engineering, The University of Western Ontario, 1151 Richmond Street, London, \\ ON, Canada N6A $5 B 7$ \\ ${ }^{3}$ Department of Chemistry, The University of Western Ontario, 1151 Richmond Street, London, ON, Canada N6A 5B7
}

Correspondence should be addressed to Elizabeth R. Gillies, egillie@uwo.ca

Received 2 January 2012; Accepted 1 March 2012

Academic Editor: Kibret Mequanint

Copyright (c) 2012 Gregory J. Zilinskas et al. This is an open access article distributed under the Creative Commons Attribution License, which permits unrestricted use, distribution, and reproduction in any medium, provided the original work is properly cited.

\begin{abstract}
Micelles formed from amphiphilic copolymers are promising materials for the delivery of drug molecules, potentially leading to enhanced biological properties and efficacy. In this work, new poly(ester amide)-poly(ethylene oxide) (PEA-PEO) graft copolymers were synthesized and their assembly into micelles in aqueous solution was investigated. It was possible to tune the sizes of the micelles by varying the PEO content of the polymers and the method of micelle preparation. Under optimized conditions, it was possible to obtain micelles with diameters less than $100 \mathrm{~nm}$ as measured by dynamic light scattering and transmission electron microscopy. These micelles were demonstrated to encapsulate and release a model drug, Nile Red, and were nontoxic to HeLa cells as measured by an MTT assay. Overall, the properties of these micelles suggest that they are promising new materials for drug delivery systems.
\end{abstract}

\section{Introduction}

While many advances have been made in the development of therapeutics to treat human diseases over the past several decades, many drugs and drug candidates still possess undesirable properties. For example, the low aqueous solubilities of hydrophobic drugs such as paclitaxel present major hurdles for their administration as the use of excipients including Cremophor EL or ethanol for drug solubilization can result in undesirable side effects upon injection [1]. In addition, many anti-cancer drugs undergo rapid elimination from circulation and lack specificity for tumor cells, leading to decreased efficacy and severe side effects $[2,3]$. Over the past couple of decades there has been significant interest in the development of drug delivery vehicles based on polymer assemblies such as spherical micelles [4-6], wormlike micelles [7], and vesicles [8-10]. These materials can enhance the solubilities of hydrophobic drugs through encapsulation. Furthermore, their nanoscale sizes can lead to significantly increased in vivo drug circulation times and tumor targeting via the enhanced permeability and retention effect [11]. Micelles have been one of the most widely investigated classes of polymer assemblies [4-6]. Thus far, a wide variety of amphiphilic copolymers such as poly(ethylene oxide)(PEO)-poly(E-caprolactone) [12], PEOpoly(propylene oxide) [13], and PEO-poly(aspartic acid) [14] have been used for the preparation of drug delivery micelles, and some of these have been demonstrated to provide enhanced therapeutic efficacy in vitro and in vivo.

Poly(ester amide)s (PEAs) are a class of polymers comprising both ester and amide linkages in their backbones. The presence of ester moieties introduces the possibility for hydrolytic degradation and enzymatic degradation by mechanisms similar to those observed for polyesters, while the amide linkages provide opportunities for enzymatic degradation and also impart some of the desirable thermal and mechanical properties that are commonly derived from polyamides [15]. By tuning the chemical structures of 
the monomers, their properties can be readily tuned [1624]. Furthermore, their monomers can be selected from simple metabolic intermediates such as amino acids and dicarboxylic acids such that their degradation should result in nontoxic products. Another advantage is that by using amino acid monomers with functional handles, PEAs with pendant functional groups can be prepared [16, 25-32]. These pendant functional handles have potential utility for the conjugation of drug molecules in delivery systems, cell signaling molecules in tissue engineering scaffolds, or simply for tuning the properties of the polymers.

In recent work, PEAs have shown promise in several biomedical applications. For example, PEAs have been used to formulate drug-loaded microparticles $[33,34]$, coatings [35-37], and hydrogels [38-40]. They have also been investigated as gene carriers [41] and as tissue engineering scaffolds [26, 42-44]. However, to the best of our knowledge, there are no examples of micellar drug delivery systems based on PEAs. While PEAs are generally hydrophobic and water insoluble, as shown in Figure 1, it was envisaged that using our previously reported PEAs that contain reactive pendant groups $[16,25,26]$, it would be possible to graft hydrophilic chains onto the PEA backbone, resulting in an amphiphilic graft copolymer. It was anticipated that the resulting amphiphilic copolymers might assemble into biodegradable micelles for drug delivery applications. While such amphiphilic polymers based on PEAs have not been previously reported, other amphiphilic graft copolymers have been demonstrated to form micelles in aqueous solution [45-49].

Described here are the synthesis and characterization of PEA-PEO graft copolymers, an investigation of their micellization, and initial work towards their application as drug carriers. A PEA backbone based on phenylalanine, lysine, 1,4-butanediol, and sebacic acid was selected based on its ease of synthesis by an interfacial method [26] and the presence of amine functional handles for conjugation of the hydrophilic blocks. PEO was chosen as the hydrophilic block for grafting due to its high water solubility, known biocompatibility in drug delivery applications, and its stealthy properties in vivo [50-53]. Several different loadings of PEO were explored, and the effects on the micelle sizes were investigated. The encapsulation and release of a model drug, Nile Red, were demonstrated, and experiments were performed to investigate the toxicity of the micelles.

\section{Experimental}

2.1. General Procedure and Methods. Polymer 1 was prepared as previously reported [26]. Unless noted otherwise, all other chemicals were purchased from commercial suppliers and used as received. Anhydrous $\mathrm{CH}_{2} \mathrm{Cl}_{2}$ was obtained by distillation over $\mathrm{CaH}_{2}$. Infrared (IR) spectra were obtained using a Bruker Tensor 27 instrument as films from $\mathrm{CH}_{2} \mathrm{Cl}_{2}$ on $\mathrm{NaCl}$ plates. ${ }^{1} \mathrm{H}$ NMR spectra were obtained at $400 \mathrm{MHz}$ on a Varian Mercury 400 Spectrometer. Chemical shifts are reported in $\mathrm{ppm}$ and are calibrated against residual solvent signals of $\mathrm{CDCl}_{3}(\delta$ 7.27). All coupling constants $(J)$ are reported in $\mathrm{Hz}$. Size exclusion chromatography
(SEC) data were obtained using a Waters 2695 separations module equipped with a Waters 2414 refractive index detector (Waters Limited, Mississauga, ON, Canda) and two PLgel $5 \mu \mathrm{m}$ mixed-D $(300 \mathrm{~mm} \times 7.5 \mathrm{~mm})$ columns connected in series (Varian, Canada). Samples $(5 \mathrm{mg} / \mathrm{mL})$ dissolved in the eluent, which comprised $10 \mathrm{mM} \mathrm{LiBr}$ and 1 vol\% triethylamine in $N, N$-dimethylformamide (DMF) at $85^{\circ} \mathrm{C}$, were injected $(100 \mu \mathrm{L})$ at a flow rate of $1 \mathrm{~mL} / \mathrm{min}$. Calibrations were performed using either polystyrene or PEO standards. Molecular weights are reported in grams $/ \mathrm{mol}$ $(\mathrm{g} / \mathrm{mol})$. Preparative SEC was performed at flow rate of $3 \mathrm{~mL} / \mathrm{min}$ using a system comprising a Waters 515 pump, a PLgel Prep $(25 \times 25 \mathrm{~mm})$ guard column, a PLgel $10 \mu \mathrm{m} 100 \AA$ $(600 \times 25 \mathrm{~mm})$ column, a PLgel $10 \mu \mathrm{m} 500 \AA(600 \times 25 \mathrm{~mm})$ column, and a Wyatt Optilab Rex Refractive Index detector. The eluent was composed of HPLC-grade DMF with 1 vol\% triethylamine. Dynamic light scattering was performed on a ZetaSizer Nano instrument from Malvern. Dialysis was performed using Spectra/Por 6 regenerated cellulose membranes from Spectrum Laboratories with a molecular weight cut-off (MWCO) of either 12000-14000 g/mol or $25000 \mathrm{~g} / \mathrm{mol}$ (Rancho Dominguez, CA, USA).

2.2. Synthesis of 4-Nitrophenyl-Carbonate-Activated PEO 5. PEO 2 ( $4.0 \mathrm{~g}, 2.0 \mathrm{mmol}, 1.0$ equiv.) and 4-nitrophenyl chloroformate $(0.81 \mathrm{~g}, 4.0 \mathrm{mmol}, 2.0$ equiv. $)$ were dissolved in $\mathrm{CH}_{2} \mathrm{Cl}_{2}(5 \mathrm{~mL})$. To this solution, pyridine $(0.90 \mathrm{~mL}$, $8.0 \mathrm{mmol}, 4.0$ equiv.) was added dropwise, and the reaction was stirred overnight. The reaction mixture was then precipitated in cold diethyl ether $(250 \mathrm{~mL})$. The precipitate was recovered, dried in vacuo, dissolved in $\mathrm{CH}_{2} \mathrm{Cl}_{2}$, and washed twice in $1 \mathrm{M} \mathrm{HCl}$. Yield: $75 \%$. ${ }^{1} \mathrm{H} \mathrm{NMR}\left(400 \mathrm{MHz}, \mathrm{CDCl}_{3}\right)$ : $\delta 8.29\left(\mathrm{~d}, 2 \mathrm{H}, J=9.0, \mathrm{Ar}-\mathrm{H}\right.$ ortho to $\left.\mathrm{NO}_{2}\right), 7.40(\mathrm{~d}, 2 \mathrm{H}$, $J=9.0$, Ar- $\mathrm{H}$ meta to $\left.\mathrm{NO}_{2}\right), 4.45-4.43\left(-\mathrm{CH}_{2}-\mathrm{O}-\mathrm{C}(\mathrm{O})-\right.$ $\mathrm{O}-$ ), 3.62 (br s, 449H, -O- $\mathrm{CH}_{2}-\mathrm{CH}_{2}-\mathrm{O}-$ ), 3.36 (s, 3H,$\left.\mathrm{O}-\mathrm{CH}_{3}\right)$. IR $\left(\mathrm{cm}^{-1}\right): 2883\left(\mathrm{sp}^{3} \mathrm{C}-\mathrm{H}\right.$ stretch$), 1769(\mathrm{C}=\mathrm{O}$ stretch), $1526\left(\mathrm{CH}_{2}\right.$ bend, $\mathrm{C}=\mathrm{C}$ ring stretch), $1468\left(\mathrm{CH}_{3}\right.$ bend, $\mathrm{C}=\mathrm{C}$ ring stretch), 1360 (symmetric $\mathrm{Ar}-\mathrm{NO}_{2}$ stretch), 1280 (Ar-O stretch), 1115 (asymmetric C-O-C stretch), 843 (out of plane $\mathrm{C}-\mathrm{H}$ on Ar bending). SEC (relative to PEO standards): $M_{n}=1700, M_{w}=1800, \mathrm{PDI}=1.06$.

2.3. Synthesis of 4-Nitrophenyl-Carbonate-Activated PEO 6. The same procedure described above for the preparation of 5 was used except that PEO 3 having a MW of 5,000 g/mol $(10 \mathrm{~g}, 2.0 \mathrm{mmol})$ was used as the starting material. Yield: $92 \% .{ }^{1} \mathrm{H}$ NMR $\left(400 \mathrm{MHz}, \mathrm{CDCl}_{3}\right): \delta 8.28(\mathrm{~d}, 2 \mathrm{H}, J=9.0$, Ar- $H$ ortho to $\left.\mathrm{NO}_{2}\right), 7.39(\mathrm{~d}, 2 \mathrm{H}, J=9.0$, Ar- $H$ meta to $\mathrm{NO}_{2}$ ), 4.46-4.44 (- $\left.\mathrm{CH}_{2}-\mathrm{O}-\mathrm{C}(\mathrm{O})-\mathrm{O}-\right), 3.65$ (br s, $449 \mathrm{H},-$ $\left.\mathrm{O}-\mathrm{CH}_{2}-\mathrm{CH}_{2}-\mathrm{O}-\right), 3.39\left(\mathrm{~s}, 3 \mathrm{H},-\mathrm{O}-\mathrm{CH}_{3}\right)$. IR $\left(\mathrm{cm}^{-1}\right): 2880$ $\left(\mathrm{sp}^{3} \mathrm{C}-\mathrm{H}\right.$ stretch), $1765(\mathrm{C}=\mathrm{O}$ stretch $), 1526\left(\mathrm{CH}_{2}\right.$ bend, $\mathrm{C}=\mathrm{C}$ ring stretch), $1462\left(\mathrm{CH}_{3}\right.$ bend, $\mathrm{C}=\mathrm{C}$ ring stretch $)$, 1380 (symmetric Ar- $\mathrm{NO}_{2}$ stretch), 1259 (Ar-O stretch), 1111 (asymmetric C-O-C stretch), 847 (out of plane $\mathrm{C}-\mathrm{H}$ on Ar bending). SEC (relative to PEO standards): $M_{n}=4500$, $M_{w}=4600, \mathrm{PDI}=1.08$.

2.4. Synthesis of PEA-PEO Graft Copolymer 7. Polymer 1 (53 mg, $19 \mu \mathrm{mol}$ of pendant amine, 1.0 equiv.), activated 


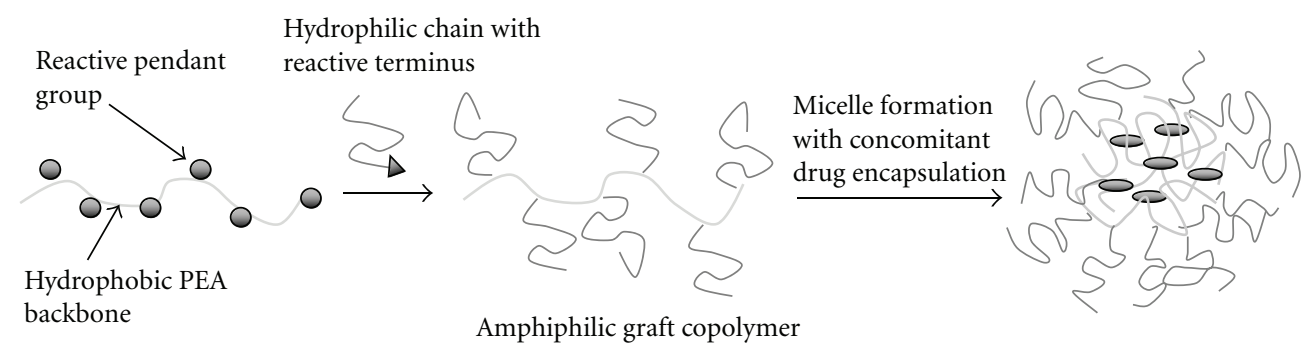

FIGURE 1: Schematic for the preparation of amphiphilic PEA graft copolymers and their assembly into micelles for drug delivery.

PEO 5 (44 mg, $22 \mu \mathrm{mol}, 1.2$ equiv.), and 4-(dimethylamino)pyridine (DMAP) $(570 \mu \mathrm{g}, 3.8 \mu \mathrm{mol}, 0.20$ equiv.) were added to a flame-dried flask under an argon atmosphere. $\mathrm{CH}_{2} \mathrm{Cl}_{2}$ (4 mL) was added to dissolve the solids. Upon dissolution, $N, N$-diisopropylethylamine (DIPEA) $(6.7 \mu \mathrm{L}$, $38 \mu \mathrm{mol}, 2.0$ equiv.) was added dropwise. The reaction mixture was stirred overnight, and then the solvent was removed in vacuo. To remove small molecule byproducts, the product was dialyzed against DMF using a $25000 \mathrm{~g} / \mathrm{mol}$ MWCO membrane. The solvent was removed in vacuo, and the off-white solid was separated from any uncoupled PEO through preparative SEC. The solvent was removed in vacuo yielding polymer 7 . Yield: $28 \% .{ }^{1} \mathrm{H}$ NMR $\left(400 \mathrm{MHz}, \mathrm{CDCl}_{3}\right)$ : $\delta$ 7.28-7.10 (m, 9H, Ph), 6.15-6.05 (m, 0.2H, -C(O)-NH$\left.\mathrm{C}_{\alpha} \mathrm{H}-\left(\mathrm{CH}_{2}\right)_{4}-\mathrm{NH}-\mathrm{C}(\mathrm{O})-\mathrm{O}-\right) 6.01$ (d, 1.8H, J $=8.2$, $\left.\mathrm{C}(\mathrm{O})-\mathrm{NH}-\mathrm{C}_{\alpha} \mathrm{H}-\mathrm{CH}_{2}-\mathrm{Ph}\right), 4.88-4.85\left(\mathrm{~m}, 1.8,-\mathrm{C}_{\alpha} \mathrm{H}-\mathrm{CH}_{2}-\right.$ $\mathrm{Ph}), 4.58-4.51(\mathrm{~m}, 0.2 \mathrm{H},-\mathrm{NH}-\mathrm{C}(\mathrm{O})-\mathrm{O}-), 4.12-4.01(\mathrm{~m}$, $4 \mathrm{H},-\mathrm{C}(\mathrm{O}) \mathrm{O}-\mathrm{CH}_{2}-$ ), 3.65 (br s, $19 \mathrm{H},-\mathrm{O}-\mathrm{CH}_{2}-\mathrm{CH}_{2}-\mathrm{O}-$ ), $3.38\left(\mathrm{~s}, 0.3 \mathrm{H},-\mathrm{O}-\mathrm{CH}_{3}\right), 3.15-3.05\left(\mathrm{~m}, 3.8 \mathrm{H},-\mathrm{C}_{\alpha} \mathrm{H}-\mathrm{CH}_{2}-\right.$ $\mathrm{Ph}), 2.21-2.12\left(\mathrm{~m}, 4 \mathrm{H},-\mathrm{NH}-\mathrm{C}(\mathrm{O})-\mathrm{CH}_{2}-\right), 1.57-1.55(\mathrm{~m}$, $\left.8 \mathrm{H},-\mathrm{C}(\mathrm{O}) \mathrm{O}-\mathrm{CH}_{2}-\mathrm{CH}_{2}-,-\mathrm{NH}-\mathrm{C}(\mathrm{O})-\mathrm{CH}_{2}-\mathrm{CH}_{2}-\right)$, $1.26-$ $1.22\left(\mathrm{~m}, 8.4 \mathrm{H},-\mathrm{NH}-\mathrm{C}(\mathrm{O})-\mathrm{CH}_{2}-\mathrm{CH}_{2}-\left(\mathrm{CH}_{2}\right)_{4}\right)$. IR $\left(\mathrm{cm}^{-1}\right)$ : 3099 (N-H stretch), 3022 ( $\mathrm{sp}^{2} \mathrm{C}-\mathrm{H}$ stretch), 2880 ( $\mathrm{sp}^{3} \mathrm{C}-$ $\mathrm{H}$ stretch), 1749 ( $\mathrm{C}=\mathrm{O}$ etser stretch), 1693 ( $\mathrm{C}=\mathrm{O}$ amide stretch), 1556 ( $\mathrm{N}-\mathrm{H}$ bending), $1527\left(\mathrm{CH}_{2}\right.$ bend, $\mathrm{C}=\mathrm{C}$ ring stretch), $1468\left(\mathrm{CH}_{3}\right.$ bend, $\mathrm{C}=\mathrm{C}$ ring stretch), $1429(\mathrm{C}-$ $\mathrm{N}$ stretch), 1107 (asymmetric C-O-C stretch), 992 (C-O stretch), 851 (symmetric C-O-C stretching), 832 (out of plane C-H on Ar bending), 758 (monosubstituted Ar C$\mathrm{H}$ bending) 687 (monosubstituted Ar C-H bending). SEC (relative to PEO standards): $M_{n}=23300, M_{w}=34700$, PDI $=1.49$.

2.5. Synthesis of PEA-PEO Graft Copolymer 8. This polymer was prepared by the same procedure described above for the preparation of copolymer 7 except that 0.85 equivalents (relative to the number of pendant amines on polymer 1 ) of PEO 6 were used. Yield: $25 \% .{ }^{1} \mathrm{H}$ NMR $(400 \mathrm{MHz}$, $\left.\mathrm{CDCl}_{3}\right): \delta 7.26-7.05(\mathrm{~m}, 9 \mathrm{H}, \mathrm{Ph}), 5.95(\mathrm{~d}, 1.8 \mathrm{H}, J=7.4,-$ $\left.\mathrm{C}(\mathrm{O})-\mathrm{NH}-\mathrm{C}_{\alpha} \mathrm{H}-\mathrm{CH}_{2}-\mathrm{Ph}\right), 4.86-4.79\left(\mathrm{~m}, 1.8,-\mathrm{C}_{\alpha} \mathrm{H}-\mathrm{CH}_{2}-\right.$ $\mathrm{Ph}), 4.51-4.42(\mathrm{~m}, 0.2 \mathrm{H},-\mathrm{NH}-\mathrm{C}(\mathrm{O})-\mathrm{O}-), 4.12-3.97(\mathrm{~m}$, $4 \mathrm{H},-\mathrm{C}(\mathrm{O}) \mathrm{O}-\mathrm{CH}_{2}-$ ), 3.65 (br s, $26 \mathrm{H},-\mathrm{O}-\mathrm{CH}_{2}-\mathrm{CH}_{2}-\mathrm{O}-$ ), $3.37\left(\mathrm{~s}, 0.2 \mathrm{H},-\mathrm{O}-\mathrm{CH}_{3}\right), 3.09-3.00\left(\mathrm{~m}, 3.8 \mathrm{H},-\mathrm{C}_{\alpha} \mathrm{H}-\mathrm{CH}_{2}-\right.$ $\mathrm{Ph}), 2.13-2.09\left(\mathrm{~m}, 4 \mathrm{H},-\mathrm{NH}-\mathrm{C}(\mathrm{O})-\mathrm{CH}_{2}-\right), 1.55-1.50(\mathrm{~m}$, $\left.8 \mathrm{H},-\mathrm{C}(\mathrm{O}) \mathrm{O}-\mathrm{CH}_{2}-\mathrm{CH}_{2}-,-\mathrm{NH}-\mathrm{C}(\mathrm{O})-\mathrm{CH}_{2}-\mathrm{CH}_{2}-\right)$, $1.23-$ $1.19\left(\mathrm{~m}, 8 \mathrm{H},-\mathrm{NH}-\mathrm{C}(\mathrm{O})-\mathrm{CH}_{2}-\mathrm{CH}_{2}-\left(\mathrm{CH}_{2}\right)_{4}\right)$. IR $\left(\mathrm{cm}^{-1}\right)$ :
3100 (N-H stretch), 3030 ( $\mathrm{sp}^{2} \mathrm{C}-\mathrm{H}$ stretch), 2883 ( $\mathrm{sp}^{3} \mathrm{C}-$ $\mathrm{H}$ stretch), 1745 ( $\mathrm{C}=\mathrm{O}$ etser stretch), 1690 ( $\mathrm{C}=\mathrm{O}$ amide stretch), 1550 ( $\mathrm{N}-\mathrm{H}$ bending), $1526\left(\mathrm{CH}_{2}\right.$ bend, $\mathrm{C}=\mathrm{C}$ ring stretch), $1468\left(\mathrm{CH}_{3}\right.$ bend, $\mathrm{C}=\mathrm{C}$ ring stretch $), 1400(\mathrm{C}-$ $\mathrm{N}$ stretch), 1115 (asymmetric C-O-C stretch), 999 (C-O stretch), 850 (symmetric C-O-C stretching), 843 (out of plane C-H on Ar bending), 750 (monosubstituted Ar C$\mathrm{H}$ bending), 690 (monosubstituted Ar C-H bending). SEC (relative to PEO standards): $M_{n}=29900, M_{w}=46900$, $\mathrm{PDI}=1.57$.

2.6. Synthesis of PEA-PEO Graft Copolymer 9. This polymer was prepared by the same procedure described above for the preparation of copolymer 7 except that 1.2 equivalents (relative to the number of pendant amines on polymer 1) of PEO 6 were used. Yield: $27 \% .{ }^{1} \mathrm{H}$ NMR (400 MHz, $\left.\mathrm{CDCl}_{3}\right)$ : 反 7.28-7.09 (m, 9H, Ph), 6.34-6.24 (br m, 0.2H, -C(O)$\left.\mathrm{NH}-\mathrm{C}_{\alpha} \mathrm{H}-\left(\mathrm{CH}_{2}\right)_{4}-\mathrm{NH}-\mathrm{C}(\mathrm{O})-\mathrm{O}-\right) 6.00(\mathrm{~d}, 1.8 \mathrm{H}, \mathrm{J}=7.6,-$ $\left.\mathrm{C}(\mathrm{O})-\mathrm{NH}-\mathrm{C}_{\alpha} \mathrm{H}-\mathrm{CH}_{2}-\mathrm{Ph}\right), 4.88-4.84\left(\mathrm{~m}, 1.8,-\mathrm{C}_{\alpha} \mathrm{H}-\mathrm{CH}_{2}-\right.$ $\mathrm{Ph}), 4.59-4.48(\mathrm{~m}, 0.2 \mathrm{H},-\mathrm{NH}-\mathrm{C}(\mathrm{O})-\mathrm{O}-), 4.12-4.01(\mathrm{~m}$, $4 \mathrm{H},-\mathrm{C}(\mathrm{O}) \mathrm{O}-\mathrm{CH}_{2}-$ ), 3.65 (br s, $45 \mathrm{H},-\mathrm{O}-\mathrm{CH}_{2}-\mathrm{CH}_{2}-\mathrm{O}-$ ), $3.37\left(\mathrm{~s}, 0.3 \mathrm{H},-\mathrm{O}-\mathrm{CH}_{3}\right), 3.12-3.03\left(\mathrm{~m}, 3.8 \mathrm{H},-\mathrm{C}_{\alpha} \mathrm{H}-\mathrm{CH}_{2}-\right.$ $\mathrm{Ph}), 2.18-2.12\left(\mathrm{~m}, 4 \mathrm{H},-\mathrm{NH}-\mathrm{C}(\mathrm{O})-\mathrm{CH}_{2}-\right)$, 1.57-1.52 (m, $\left.8 \mathrm{H},-\mathrm{C}(\mathrm{O}) \mathrm{O}-\mathrm{CH}_{2}-\mathrm{CH}_{2}-,-\mathrm{NH}-\mathrm{C}(\mathrm{O})-\mathrm{CH}_{2}-\mathrm{CH}_{2}-\right)$, $1.28-$ $1.22\left(\mathrm{~m}, 8 \mathrm{H},-\mathrm{NH}-\mathrm{C}(\mathrm{O})-\mathrm{CH}_{2}-\mathrm{CH}_{2}-\left(\mathrm{CH}_{2}\right)_{4}\right)$. IR $\left(\mathrm{cm}^{-1}\right)$ : 3110 (N-H stretch), 3032 ( $\mathrm{sp}^{2} \mathrm{C}-\mathrm{H}$ stretch), 2886 ( $\mathrm{sp}^{3} \mathrm{C}-$ $\mathrm{H}$ stretch), 1755 ( $\mathrm{C}=\mathrm{O}$ ester stretch), 1696 ( $\mathrm{C}=\mathrm{O}$ amide stretch), 1551 ( $\mathrm{N}-\mathrm{H}$ bending), $1528\left(\mathrm{CH}_{2}\right.$ bend, $\mathrm{C}=\mathrm{C}$ ring stretch), $1468\left(\mathrm{CH}_{3}\right.$ bend, $\mathrm{C}=\mathrm{C}$ ring stetch $), 1405(\mathrm{C}-$ $\mathrm{N}$ stretch), 1114 (assymetric C-O-C stretch), 979 (C-O stretch), 853 (symmetric C-O-C stretching), 843 (out of plane C-H on Ar bending), 737 (monosubstituted Ar C$\mathrm{H}$ bending) 692 (monosubstituted Ar C-H bending). SEC (relative to PEO standards): $M_{n}=30500, M_{w}=49700$, PDI $=1.63$.

2.7. Procedure for Micelle Formation. The PEA-PEO graft copolymer $(2.0 \mathrm{mg})$ was dissolved in either $0.05,0.6$, or $0.8 \mathrm{~mL}$ of THF. The solution was stirred rapidly while distilled water was rapidly added to provide a final volume of $2 \mathrm{~mL}$. THF was then removed by dialysis against distilled water using a Spectra/Por regenerated cellulose membrane with a MWCO of $12000-14000 \mathrm{~g} / \mathrm{mol}$.

2.8. Determination of the Critical Aggregation Concentration for Copolymer 9. Micelles were prepared as described above 
from copolymer 9. Nile Red $(0.94 \mathrm{mg}, 3.0 \mu \mathrm{mol})$ was dissolved in $9 \mathrm{~mL}$ of $\mathrm{CH}_{2} \mathrm{Cl}_{2}$, and $0.1 \mathrm{~mL}$ of this solution was added to a series of 12 vials. The $\mathrm{CH}_{2} \mathrm{Cl}_{2}$ was removed under a stream of nitrogen. A series of concentrations of the micelle suspension ranging from $0.5 \mu \mathrm{g} / \mathrm{mL}$ to $1 \mathrm{mg} / \mathrm{mL}$ was prepared by dilution with $\mathrm{pH} 7.4,100 \mathrm{mM}$ phosphate buffer. The micelle suspensions were added to the vials containing Nile Red, and were allowed to equilibrate with stirring for 40 hours. The fluorescence spectra were obtained on a QM-4 SE spectrometer from Photon Technology International (PTI), equipped with double excitation and emission monochromators. An excitation wavelength of $550 \mathrm{~nm}$ was used for Nile Red and the emission spectra were recorded from 565 to $700 \mathrm{~nm}$. The maximum emission intensity was recorded for each micelle concentration.

2.9. Transmission Electron Microscopy. The micelle suspension (prepared as described above, then diluted to $0.2 \mathrm{mg} / \mathrm{mL}$ ) was placed on a Formvar/Carbon grid and was left to stand for $5 \mathrm{~min}$. The excess solution was then blotted off using a piece of filter paper. The resulting sample was dried in air overnight before imaging. Imaging was performed using a Phillips CM10 microscope operating at $80 \mathrm{kV}$ with a $40 \mu \mathrm{m}$ aperture.

2.10. Encapsulation and Release of Nile Red. Micelles formed from copolymer 9 were prepared as described above except that Nile Red $(0.5 \mathrm{mg}, 1.6 \mu \mathrm{mol})$ was dissolved in the THF solution. After removal of the THF by dialysis, centrifugation (6000 rpm for $30 \mathrm{~min}$ ) was used to remove any precipitated Nile Red. The micelle suspension was placed in a SlideA-Lyzer dialysis cassette and kept at $37^{\circ} \mathrm{C}$ in either $\mathrm{pH}$ $7.4,100 \mathrm{mM}$ phosphate buffer or $\mathrm{pH} 5.0,100 \mathrm{mM}$ citric acid/phosphate buffer. The fluorescence spectrum of the micelle suspension from the cassette was obtained every hour (QM-4 SE spectrometer from Photon Technology International (PTI) as above). An excitation wavelength of $550 \mathrm{~nm}$ was used, and emission spectra were recorded from 565 to $700 \mathrm{~nm}$. To correct for fluctuations in the fluorometer lamp intensity, the measurement at each time point was compared to that of a standard of Nile Red in THF that was covered in aluminum foil and kept in fridge.

2.11. MTT Assay. HeLa cells were cultured at $37^{\circ} \mathrm{C}$ and $5 \% \mathrm{CO}_{2}$ in Dulbecco's modified Eagle medium (DMEM) (Invitrogen) supplemented with $10 \%(\mathrm{v} / \mathrm{v})$ fetal bovine serum (Invitrogen). The cells were seeded into 88 wells of a 96-well plate (Nunclon TC treated) at a density of $2 \times$ $10^{3}$ cells per well in a final volume of $100 \mu \mathrm{L}$ of DMEM containing 10\% (v/v) serum and antibiotics (penicillin and streptomycin, 100 units $/ \mathrm{mL}$ each). Cells were allowed to adhere for 24 hours at $37^{\circ} \mathrm{C}$ in a humidified incubator with $5 \% \mathrm{CO}_{2}$. After 24 hours the growth media were aspirated. Control cells were then grown in growth media alone while those subjected to the micelle suspension were incubated in two-fold decreasing concentrations from $2 \mathrm{mg} / \mathrm{ml}$ to $0.0039 \mathrm{mg} / \mathrm{mL}$ in growth media at each concentration. 8 replicates per concentration were performed. After 48 hours, the media were aspirated and then $100 \mu \mathrm{L}$ of fresh media and
$10 \mu \mathrm{L}$ of MTT solution ( $5 \mathrm{mg} / \mathrm{mL}$ ) were added to each well and incubated for another 4 hours. The media were aspirated and the formazan product was solubilized by addition of $50 \mu \mathrm{L}$ of DMSO to each well. The absorbance of each well was measured at $540 \mathrm{~nm}$ using a plate reader (Tecan Safire), and after subtraction of the blank, the result was compared to that of the control cells that were not exposed to micelles in order to calculate the relative cell viability.

\section{Results and Discussion}

3.1. Polymer Synthesis and Characterization. PEA 1 (Figure 2) was prepared by an interfacial polycondensation method as previously reported [26]. This polymer was composed of sebacic acid, 1,4-butanediol, and an approximately 9:1 ratio of phenylalanine: lysine randomly incorporated. The resulting material had an weight average molecular weight $\left(M_{w}\right)$ of $89600 \mathrm{~g} / \mathrm{mol}$ and a polydispersity index (PDI) of 1.83, as measured by size exclusion chromatography (SEC) in DMF relative to polystyrene standards and a $M_{w}$ of 32100 and PDI of 1.71 relative to PEO standards. It should be noted that the discrepancy in molecular weights (MWS) obtained by these different calibration methods can be attributed to the large difference in hydrodynamic volumes of PEO and polystyrene in $\mathrm{DMF}$

PEO with a methyl ether group at one terminus, an alcohol at the other terminus, and a MW of either $2000 \mathrm{~g} / \mathrm{mol}$ (2) or $5000 \mathrm{~g} / \mathrm{mol}$ (3) was activated by reaction with 4nitrophenyl chloroformate (4) to form the 4-nitrophenylcarbonate-activated polymers $\mathbf{5}$ and $\mathbf{6}$ as shown in Figure 2. Subsequently, these activated PEOs were reacted with PEA 1 in $\mathrm{CH}_{2} \mathrm{Cl}_{2}$ in the presence of 4-dimethylaminopyridine (DMAP) as a catalyst and N,N-diisopropylethylamine (DIPEA) as a base. In the case of the activated PEO 5, 1.2 equivalents were used in the reaction relative to the number of pendant amines in the PEA, to provide copolymer 7. For PEO 6 either 0.85 or 1.2 equivalents of $\mathrm{PEO}$ were used in the reaction, to provide copolymers 8 and $\mathbf{9}$. This was done to obtain PEA-PEO copolymers with different PEO content and to determine the effect of the number of equivalents of $\mathrm{PEO}$ on the conjugation yield. Preliminary work indicated that increasing the number of PEO equivalents beyond 1.2 did not lead to significant increases in conjugation yield, so higher quantities of activated PEO were not investigated further.

Following the reaction, various purification methods were explored in order to remove the uncoupled PEO as well as other reaction byproducts such as 4-nitrophenol, DMAP, and DIPEA. Surprisingly, while successful in removing the low MW molecules, $\mathrm{CH}_{2} \mathrm{Cl}_{2} / \mathrm{H}_{2} \mathrm{O}$ extractions or dialysis in water using molecular weight cut-offs as high as $50000 \mathrm{~g} / \mathrm{mol}$ were unsuccessful in removing the free $\mathrm{PEO}$, as a peak assigned to free PEO was still observed in the SEC trace of the product (Figure 3(a)). This can likely be attributed to dimerization of the unreacted PEO upon the breakdown of some 4-nitrophenyl carbonates, and the resulting difficultly in removing higher MW PEO by dialysis. A comprehensive study of the dialysis membrane cut-offs for the removal of 

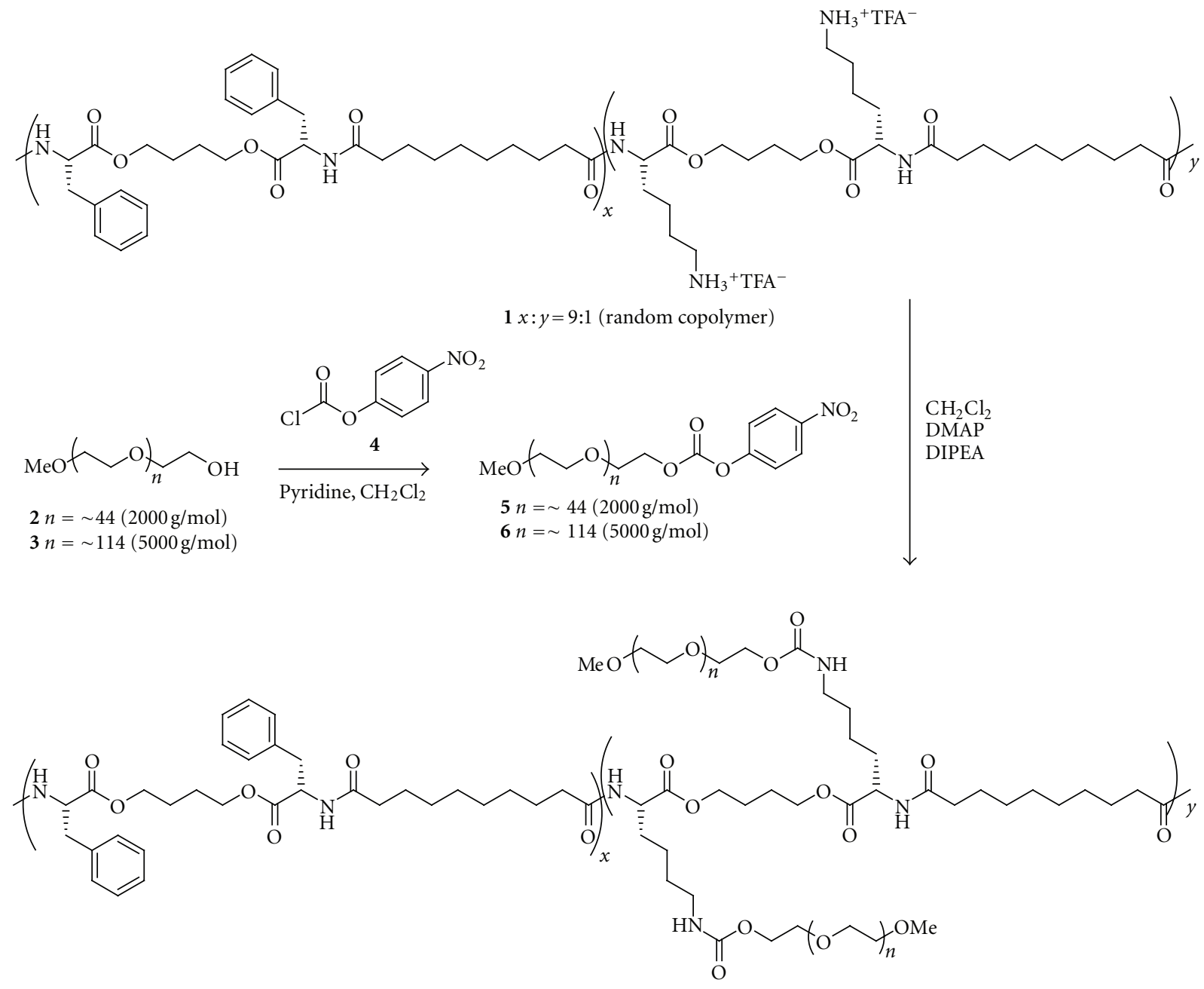

7 (from 1 and 1.2 equiv. of 5 per pendant amine) 8 (from 1 and 0.85 equiv. of $\mathbf{6}$ per pendant amine)

9 (from 1 and 1.2 equiv. of 6 per pendant amine)

Figure 2: Synthesis of PEA-PEO graft copolymers 7-9.

different MWs of PEOs is currently underway in our lab. However, in the meantime, preparative SEC was successful in removing the free PEO as shown in Figure 3(b).

Following the removal of free PEO, the degree of lysine amine functionalization was quantified by NMR spectroscopy. As shown in Table 1, using 1.2 equivalents of activated PEO, the degree of conjugation was approximately $50 \%$ for both the $2000 \mathrm{~g} / \mathrm{mol}$ and $5000 \mathrm{~g} / \mathrm{mol} \mathrm{PEO}$. Using only 0.85 equivalents of the $5000 \mathrm{~g} / \mathrm{mol}$ PEO led to a somewhat lower degree of functionalization of only $29 \%$. As expected, the resulting $M_{w}$ did increase with the degree of coupling and with the MW of the PEO. It should be noted that these data are expected to be underestimates of the MW due to the branched nature of these polymers [54].

3.2. Preparation and Characterization of Micelles. Several different methods of micelle formation were investigated in preliminary work. Nanoprecipitation, solvent exchange, thin film hydration, and chloroform emulsion evaporation were all investigated for their abilities to form nanosized micelles with low polydispersities as measured by dynamic light scattering (DLS). It was found that nanoprecipitation best met these criteria and was therefore chosen as the method for subsequent work. In short, the copolymer was dissolved in tetrahydrofuran (THF), and then water was added with rapid stirring. Finally, THF was removed by dialysis against water.

The $\mathrm{z}$-average micelle diameters and polydispersity indices are shown in Table 2, and representative DLS traces are shown in Figure 4. Initially, water was added to the THF solution of polymer such that the resulting solution contained $1 \mathrm{mg} / \mathrm{mL}$ of polymer in a 2.5 volume \% solution of THF in water prior to dialysis. This led to micelles with zaverage diameters of $123 \mathrm{~nm}$ for $7,114 \mathrm{~nm}$ for 8 , and $60 \mathrm{~nm}$ for 9. This decrease in micelle size was expected as the PEO content increases from copolymers 7-9 because increased 
TABLE 1: Characterization data for PEA-PEO graft copolymers 7-9.

\begin{tabular}{|c|c|c|c|c|c|}
\hline Polymer & Equivalents of activated $\mathrm{PEO}^{\mathrm{a}}$ & PEO MW $(\mathrm{g} / \mathrm{mol})$ & Degree of lysine functionalization ${ }^{\mathrm{b}}$ & $M_{w}(\mathrm{~g} / \mathrm{mol})^{\mathrm{c}}$ & $\mathrm{PDI}^{\mathrm{c}}$ \\
\hline 7 & 1.2 & 2000 & $53 \%$ & 34700 & 1.49 \\
\hline 8 & 0.85 & 5000 & $29 \%$ & 46900 & 1.57 \\
\hline 9 & 1.2 & 5000 & $50 \%$ & 49700 & 1.63 \\
\hline
\end{tabular}

${ }^{a}$ During synthesis, relative to the number of pendant amine groups on PEA 1.

${ }^{\mathrm{b}}$ Based on ${ }^{1} \mathrm{H}$ NMR spectroscopy.

${ }^{\mathrm{c}}$ Based on SEC.

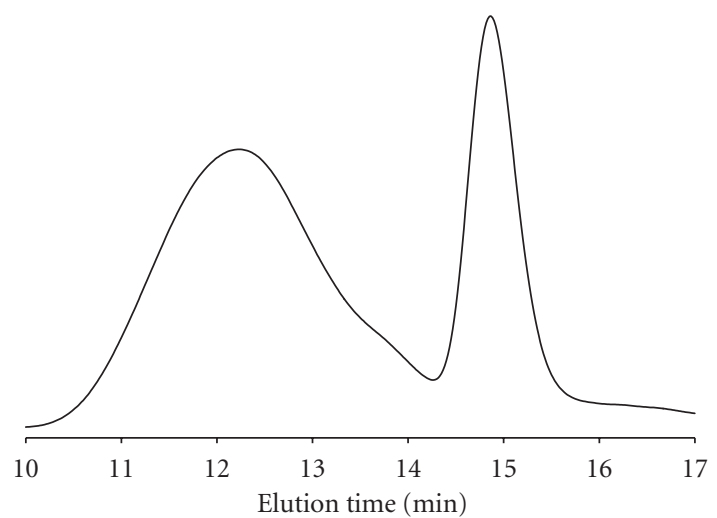

(a)

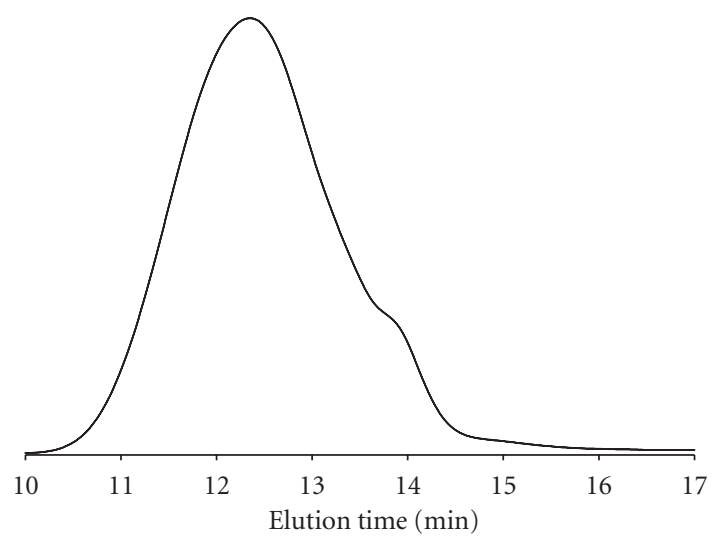

(b)

FIGURE 3: SEC chromatograms of copolymer 9 (a) prior to and (b) following purification by preparative SEC.

PEO content would be expected to reduce the intermolecular aggregation between the polymer chains, leading to smaller micelles that are composed of fewer polymer chains. To test this hypothesis, the critical aggregation concentration (CAC) of copolymer 9 was measured by Nile Red (Figure 5(a)) encapsulation. As shown in Figure 5(b), no CAC was detected and a linear relationship was observed between Nile Red fluorescence and copolymer concentration at concentrations down to $0.5 \mu \mathrm{g} / \mathrm{mL}$, suggesting that the copolymer is capable of forming unimolecular micelles.

The micelle size was also found to be dependent on the method of micelle preparation. For example, the addition of water to the THF solution of polymer such that the content of the solution was $30 \mathrm{vol} \%$ THF prior to dialysis, while maintaining a copolymer concentration of $1 \mathrm{mg} / \mathrm{mL}$ led to a $\mathrm{z}$-average micelle size of $252 \mathrm{~nm}$ for copolymer 7 and $143 \mathrm{~nm}$ for copolymer 9. A 40 vol\% THF solution led to a $\mathrm{z}$-average size of $187 \mathrm{~nm}$ for copolymer 9. This can likely be explained as follows. In THF both the PEA and PEO blocks are soluble, so the polymers exist in solution as individual chains. As water is added, the hydrophobic PEA block becomes insoluble and collapses to form the micelle core. If a sufficient amount of water is added rapidly by the initial injection prior to dialysis, the individual molecules or small aggregates are trapped as small micelles. On the other hand, if sufficient THF is present in the solution prior to dialysis, the micelles are not trapped and the slow removal of THF by dialysis allows time for the PEA blocks of multiple polymer chains to aggregate, forming larger multimolecular micelles. Thus the micelle size can be tuned by the amount of water added to the THF prior to dialysis. This could be advantageous if different micelle sizes are desired for different applications. Overall, it should also be noted that in all cases, the micelles had relatively low PDIs and very good batch-to-batch reproducibility, as indicated by the low standard deviations between batches (Table 2).

Based on the fact that materials with diameters $<100 \mathrm{~nm}$ are generally considered ideal for in vivo applications as they can circulate in the blood without rapid removal by the reticuloendothelial system [55], copolymer 9 was selected from the 3 copolymers for subsequent work. To verify the micelle sizes that were measured by DLS, TEM measurements were also performed. As shown in Figure 6, micelles prepared using the $2.5 \%$ THF solution followed by dialysis had sizes on the order of $30 \mathrm{~nm}$. This size reduction with respect to the DLS measurements is likely a result of the difference between the hydrated micelles measured in solution versus the micelles in the dry state measured by TEM. While these small micelles are of most interest for biomedical applications, those prepared from copolymer 9 from $40 \%$ THF solution were also imaged had sizes on the order of 100-200 nm. These results confirm that the sizes measured by DLS did reflect the relative sizes of the different micelle samples.

3.3. Investigation of Micelles Formed from Copolymer 9: Model Drug Encapsulation and Toxicity Evaluation. In order to demonstrate that micelles formed from copolymer 9 have potential utility as drug delivery vehicles, the encapsulation and release of a model drug, Nile Red, was investigated. This is a hydrophobic dye molecule that exhibits significant fluorescence when incorporated into hydrophobic environments 
TABLE 2: Characterization of micelles formed by copolymers 7-9 by DLS. z-average micelle diameters represent the means of the measurement data for 3 different batches of micelles.

\begin{tabular}{lccc}
\hline Polymer & THF content of micelle suspension prior to dialysis (vol\%) & z-average micelle diameter (nm) & Micelle PDI \\
\hline $\mathbf{7}$ & 2.5 & $123 \pm 2$ & $0.15 \pm 0.001$ \\
7 & 30 & $252 \pm 1$ & $0.04 \pm 0.03$ \\
$\mathbf{8}$ & 2.5 & $114 \pm 1$ & $0.13 \pm 0.01$ \\
$\mathbf{9}$ & 2.5 & $60 \pm 0.4$ & $0.29 \pm 0.01$ \\
$\mathbf{9}$ & 30 & $143 \pm 1$ & $0.16 \pm 0.02$ \\
$\mathbf{9}$ & 40 & $187 \pm 0.5$ & $0.15 \pm 0.01$ \\
\hline
\end{tabular}

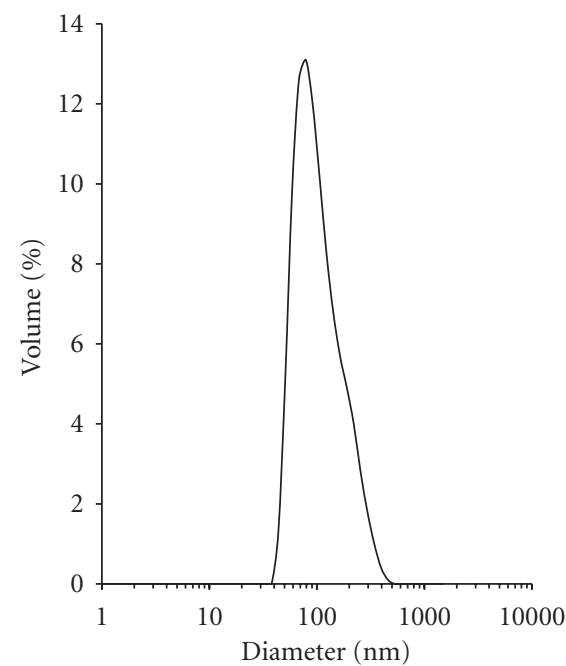

(a)

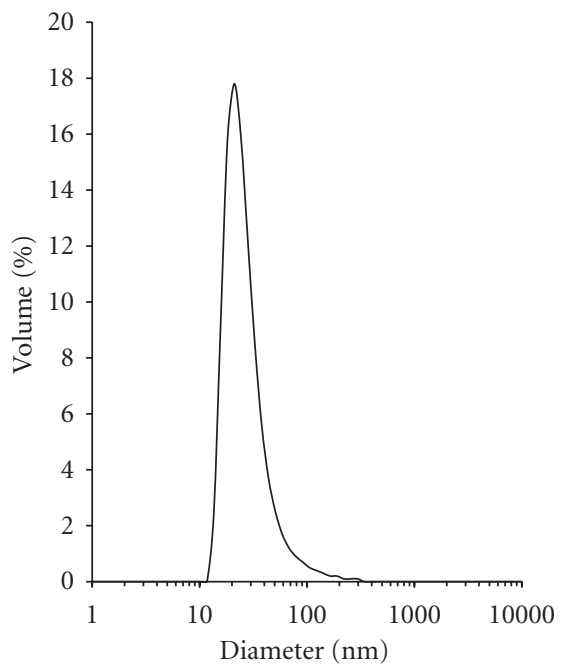

(d)

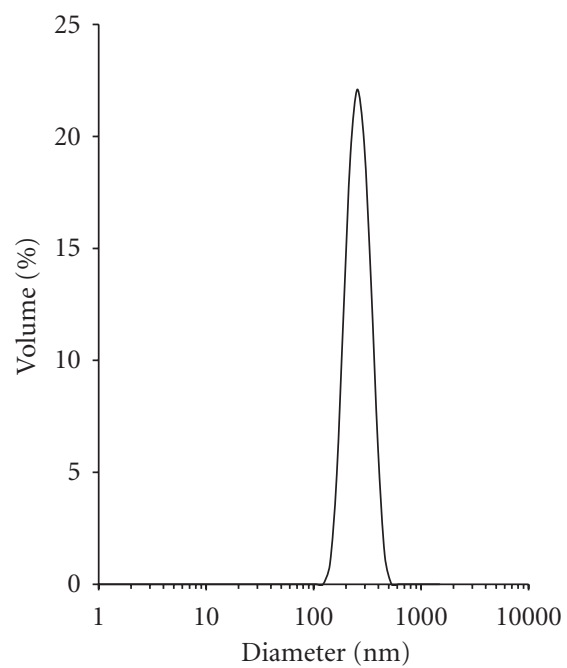

(b)

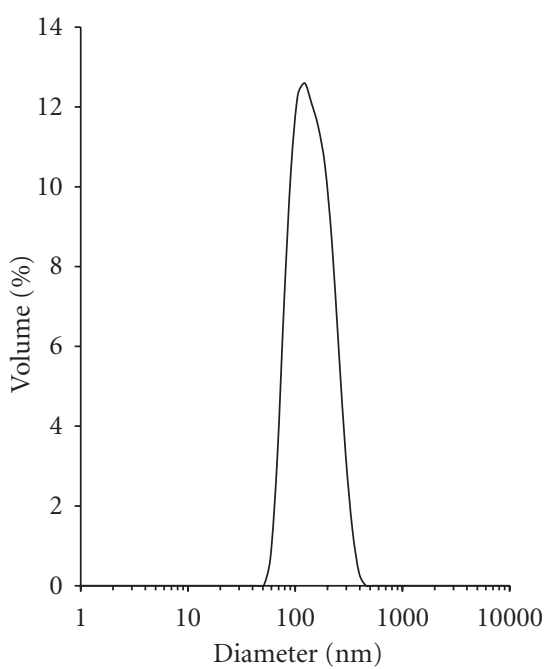

(e)

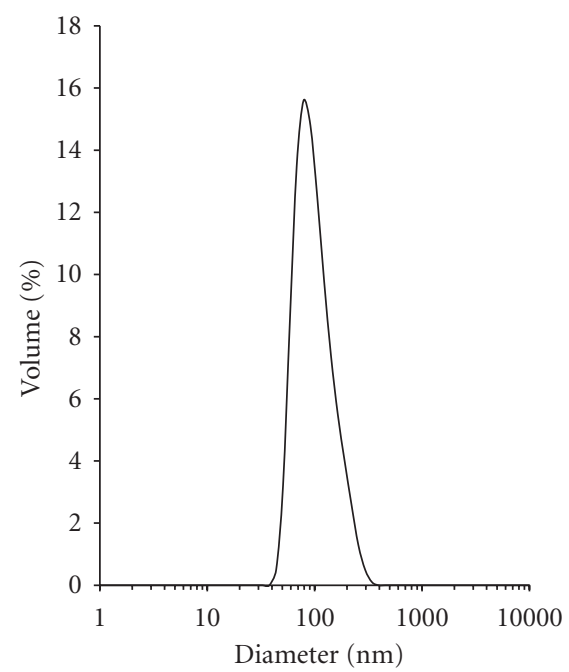

(c)

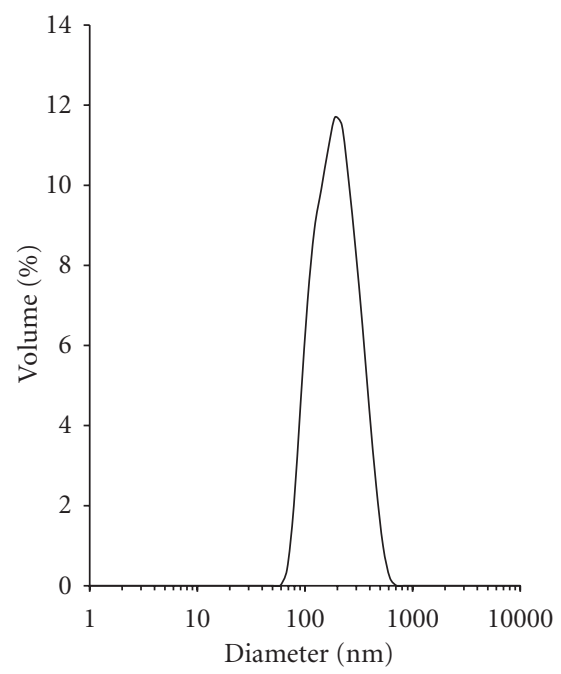

(f)

FIGURE 4: Representative DLS traces for micelles formed from copolymers 7-9 by dialyzing (against water) THF/water suspensions of the micelles containing varying THF content: (a) copolymer 7 from 2.5 vol\% THF; (b) copolymer 7 from 30 vol\% THF; (c) copolymer 8 from 2.5 vol\% THF; (d) copolymer 9 from 2.5 vol\% THF; (e) copolymer 9 from 30 vol\% THF; (f) copolymer 9 from 40 vol\% THF.

such as the cores of micelles, but negligible fluorescence in aqueous solutions due to its very low solubility $[56,57]$. It was encapsulated into the micelles by dissolving it in the THF solution along with the copolymer during the micelle preparation. Following the addition of water and removal of
THF by dialysis, any precipitated unencapsulated Nile Red was removed by centrifugation. The release of Nile Red was then monitored by fluorescence spectroscopy. As shown in Figure 7, at pH 7.4 Nile Red was completely released from the micelles over a period of approximately 15 hours. At pH 


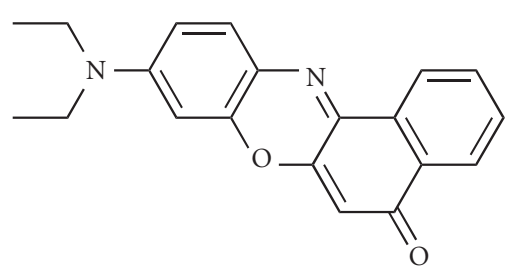

(a)

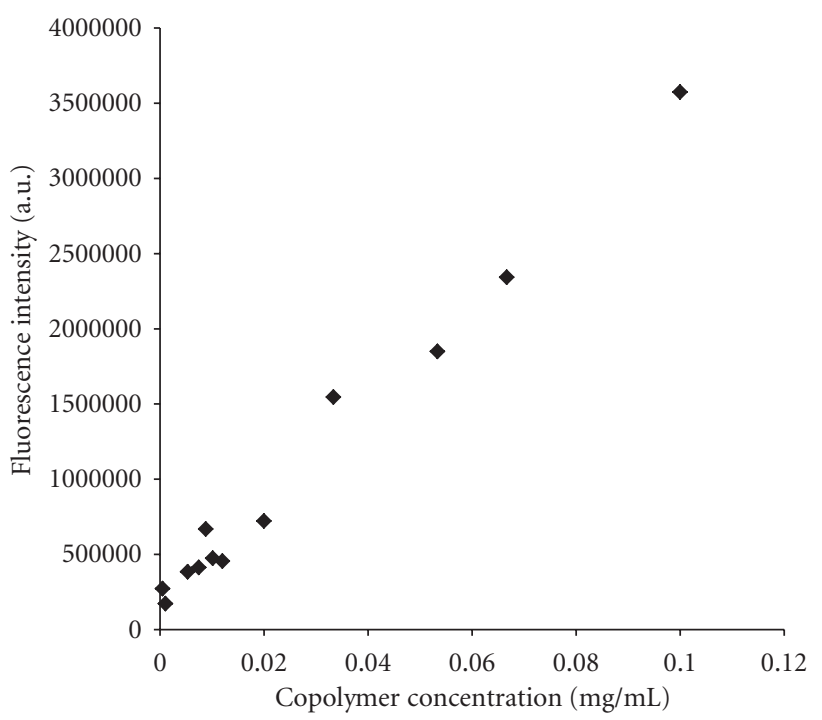

(b)

Figure 5: (a) Chemical structure of Nile Red; (b) fluorescence intensity of Nile Red as a function of copolymer concentration, illustrating a relatively linear relationship between concentration and fluorescence intensity over the concentration range from 0.5 to $100 \mu \mathrm{g} / \mathrm{mL}$.

5.0, the release was slightly faster, reaching completion over a period of 12 hours. This can be attributed to two possible causes. First, protonation of residual pendant amine groups on the PEA backbone would increase the hydrophilicity of the micelle core, accelerating drug release. Secondly, partial protonation of the aniline nitrogen of Nile Red at $\mathrm{pH} 5.0$ would make the model drug molecule more hydrophilic, favoring its release into the aqueous environment. Overall, these release rates are in a range that would be reasonable for drug delivery applications.

Finally, the toxicity of micelles composed of copolymer 9 was also investigated. Varying concentrations of micelles ranging from $4 \mu \mathrm{g} / \mathrm{mL}$ to $2 \mathrm{mg} / \mathrm{mL}$ were added to $\mathrm{HeLa}$ cells. This upper limit was based on the maximum micelle concentration of approximately $20 \mathrm{mg} / \mathrm{mL}$ that could readily be prepared in pure water and then diluted 10-fold into cell culture media. After incubation for 48 hours, an MTT assay [58] was performed to assess cell viability. As shown in Figure 8 , toxicity (as defined by a cell viability $<70 \%$ of the blank) [59] was not detected at any of these concentrations. While further studies must be performed to assess the toxicity of the micelles in vivo, the lack of toxicity of the materials even at the high $2 \mathrm{mg} / \mathrm{mL}$ concentration in vitro suggests that they should be well tolerated.

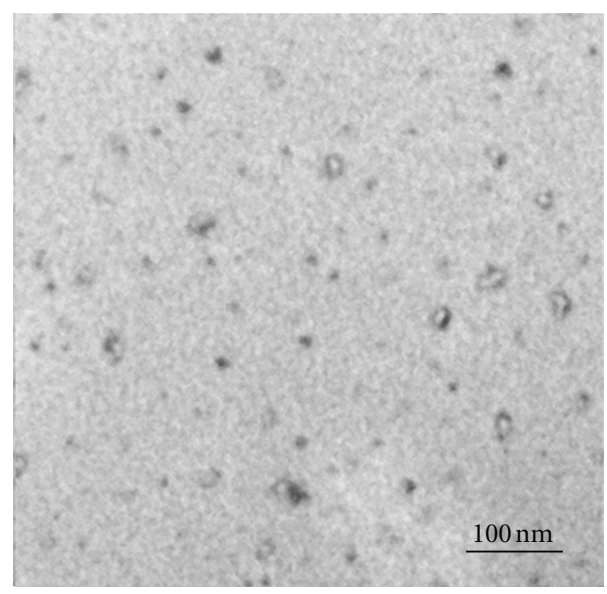

(a)

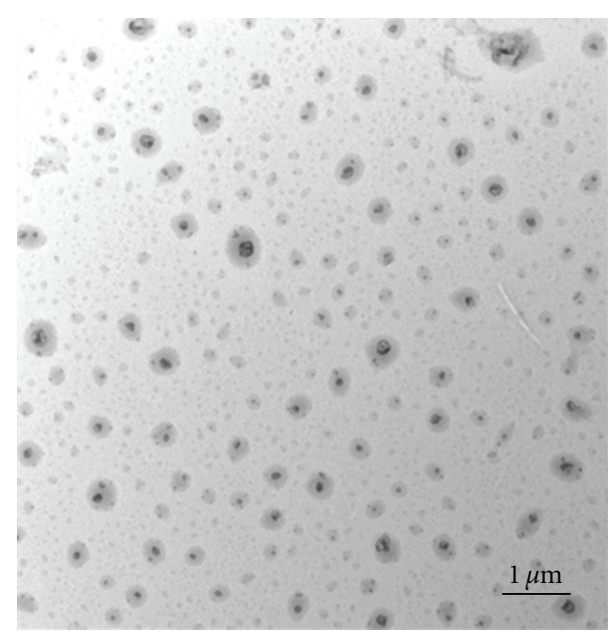

(b)

Figure 6: TEM images of micelles formed from copolymer 9 by dialyzing (against water) THF/water suspensions of the micelles containing (a) $2.5 \mathrm{vol} \%$ THF and (b) 40 vol\% THF.

\section{Conclusions}

Amphiphilic PEA-PEO graft copolymers were prepared for the first time by the reaction of 4-nitrophenyl-carbonateactivated PEO with the pendant amine groups in a PEA containing lysine residues. Varying PEO content was achieved by varying the MW of the PEO chains and by using different equivalents of PEO. Nanoprecipitation using THF and water was found to be the most effective method for micelle formation, and it was demonstrated that the micelle sizes could be tuned by the manner in which the water was added. Micelles with diameters of less than $100 \mathrm{~nm}$ were obtained from copolymer 9 , as measured by DLS and TEM. This diameter should be ideal for circulation in vivo. It was demonstrated that these micelles were capable of encapsulating the model hydrophobic drug Nile Red and releasing it over a period of 12 to 15 hours, depending on the $\mathrm{pH}$ of the solution. Furthermore, the micelles were found to be nontoxic to HeLa cells in vitro. Overall, these results suggest that micelles comprising PEA-PEO graft copolymers 


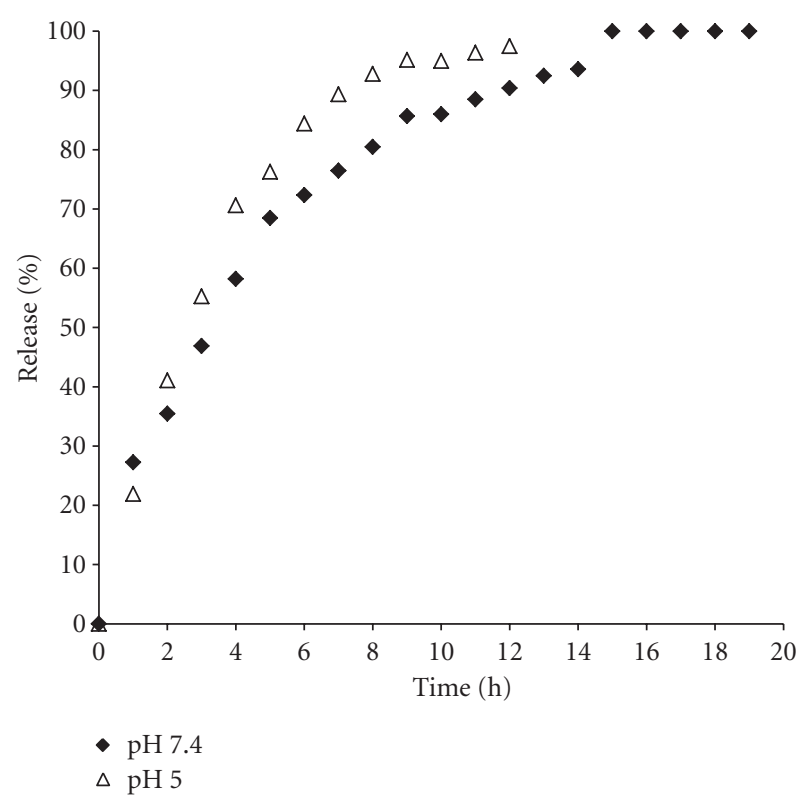

Figure 7: Release rate at pHs 7.4 and 5.0 of the hydrophobic dye Nile Red from micelles formed from copolymer 9.

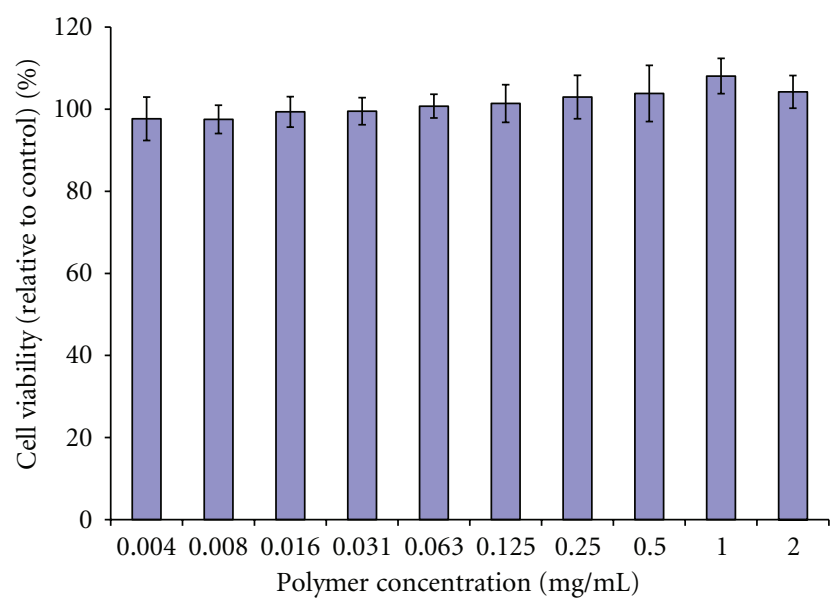

FIGURE 8: Assessment of the in vitro toxicity of micelles formed from copolymer 9. An MTT assay was performed following 48 hours of incubation of varying concentrations of micelles with HeLa cells.

are promising new carriers for drug delivery applications. Future work will focus on studying the biodegradability of the micelles, the encapsulation of drug molecules and further assessment of the micelles both in vitro and in vivo.

\section{Acknowledgments}

The authors thank the Natural Sciences and Engineering Research Council of Canada and the Canada Research Chairs program for financial support of this research. Bethany Turowec is thanked for performing the MTT assay.

\section{References}

[1] J. M. Terwogt, B. Nuijen, W. W. Huinink, and J. H. Beijnen, "Alternative formulations of paclitaxel," Cancer Treatment Reviews, vol. 23, no. 2, pp. 87-95, 1997.

[2] J. L. Arias, "Drug targeting strategies in cancer treatment: an overview," Mini-Reviews in Medicinal Chemistry, vol. 11, no. 1, pp. 1-17, 2011.

[3] L. H. Reddy, "Drug delivery to tumours: recent strategies," Journal of Pharmacy and Pharmacology, vol. 57, no. 10, pp. 1231-1242, 2005.

[4] C. Oerlemans, W. Bult, M. Bos, G. Storm, J. F. Nijsen, and W. E. Hennink, "Polymeric micelles in anticancer therapy: targeting, imaging and triggered release," Pharmaceutical Research, vol. 27, no. 12, pp. 2569-2589, 2010.

[5] V. P. Torchilin, "Polymeric micelles for therapeutic applications in medicine," Nanoscience and Nanotechnology, vol. 9, pp. 261-299, 2010.

[6] A. S. Mikhail and C. Allen, "Block copolymer micelles for delivery of cancer therapy: transport at the whole body, tissue and cellular levels," Journal of Controlled Release, vol. 138, no. 3, pp. 214-223, 2009.

[7] S. Cai, K. Vijayan, D. Cheng, E. M. Lima, and D. E. Discher, "Micelles of different morphologies-advantages of worm-like filomicelles of PEO-PCL in paclitaxel delivery," Pharmaceutical Research, vol. 24, no. 11, pp. 2099-2109, 2007.

[8] F. Meng, Z. Zhong, and J. Feijen, "Stimuli-responsive polymersomes for programmed drug delivery," Biomacromolecules, vol. 10, no. 2, pp. 197-209, 2009.

[9] D. A. Christian, S. Cai, D. M. Bowen, Y. Kim, J. D. Pajerowski, and D. E. Discher, "Polymersome carriers: from self-assembly to siRNA and protein therapeutics," European Journal of Pharmaceutics and Biopharmaceutics, vol. 71, no. 3, pp. 463474, 2009.

[10] R. P. Brinkhuis, F. P. J. T. Rutjes, and J. C. M. van Hest, "Polymeric vesicles in biomedical applications," Polymer Chemistry, vol. 2, no. 7, pp. 1449-1462, 2011.

[11] H. Maeda, J. Wu, T. Sawa, Y. Matsumura, and K. Hori, "Tumor vascular permeability and the EPR effect in macromolecular therapeutics: a review," Journal of Controlled Release, vol. 65, no. 1-2, pp. 271-284, 2000.

[12] Y. Y. Diao, H. Y. Li, Y. H. Fu et al., "Doxorubicin-loaded PEGPCL copolymer micelles enhance ctyotoxicity and intracellular accumulation of doxorubicin in adriamycin-resistant tumor cells," International Journal of Nanomedicine, vol. 6, pp. 19551962, 2011.

[13] W. Zhang, Y. Shi, Y. Chen, J. Hao, X. Sha, and X. Fang, "The potential of Pluronic polymeric micelles encapsulated with paclitaxel for the treatment of melanoma using subcutaneous and pulmonary metastatic mice models," Biomaterials, vol. 32, no. 25, pp. 5934-5944, 2011.

[14] G. S. Kwon, S. Suwa, M. Yokoyama, T. Okano, Y. Sakurai, and K. Kataoka, "Enhanced tumor accumulation and prolonged circulation times of Micelle-forming poly(ethylene oxideaspartate) block copolymer-adriamycin conjugates," Journal of Controlled Release, vol. 29, no. 1-2, pp. 17-23, 1994.

[15] A. Rodriguez-Galan, L. Franco, and J. Puiggali, "Degradable poly(ester amide)s for biomedical applications," Polymers, vol. 3, no. 1, pp. 65-99, 2011.

[16] K. M. Atkins, D. Lopez, D. K. Knight, K. Mequanint, and E. R. Gillies, "A versatile approach for the syntheses of Poly(ester amide)s with pendant functional groups," Journal of Polymer Science A, vol. 47, no. 15, pp. 3757-3772, 2009. 
[17] R. Katsarava, V. Beridze, N. Arabuli, D. Kharadze, C. C. Chu, and C. Y. Won, "Amino acid-based bioanalogous polymers. Synthesis, and study of regular poly(ester amide)s based on bis(alpha-amino acid) alpha,omega-alkylene diesters, and aliphatic dicarboxylic acids," Journal of Polymer Science A, vol. 37, no. 4, pp. 391-407, 1999.

[18] K. Guo and C. C. Chu, "Synthesis, characterization, and biodegradation of copolymers of unsaturated and saturated poly(ester amide)s," Journal of Polymer Science A, vol. 45, no. 9, pp. 1595-1606, 2007.

[19] J. Montane, E. Armelin, A. Rodriguez-Galan, and J. Puiggali, "Comparative degradation data of polyesters and related poly(ester amide)s derived from 1,4-butanediol, sebacic acid, and alpha-amino acids," Journal of Applied Polymer Science, vol. 85, no. 9, pp. 1815-1824, 2002.

[20] E. Armelin, N. Paracuellos, A. Rodriguez-Galan, and J. Puiggali, "Study on the degradability of poly(ester amide)s derived from the alpha-amino acids glycine, and L-alanine containing a variable amide/ester ratio," Polymer, vol. 42, no. 19, pp. 7923-7932, 2001.

[21] N. Paredes, A. Rodriguez-Galan, J. Puiggali, and C. Peraire, "Studies on the biodegradation and biocompatibility of a new poly (ester amide) derived from L-alanine," Journal of Applied Polymer Science, vol. 69, no. 8, pp. 1537-1549, 1998.

[22] N. Paredes, A. Rodriguez-Galan, and J. Puiggali, "Synthesis and characterization of a family of biodegradable poly(ester amide)s derived from glycine," Journal of Polymer Science A, vol. 36, no. 8, pp. 1271-1282, 1998.

[23] N. Paredes, M. T. Casas, and J. Puiggali, "Packing of sequential poly(ester amide)s derived from diols, dicarboxylic acids, and amino acids," Macromolecules, vol. 33, no. 24, pp. 9090-9097, 2000.

[24] Y. Saotome, T. Miyazawa, and T. Endo, "Novel enzymatically degradable polymers comprising alpha -amino acid, 1,2ethanediol, and adipic acid," Chemistry Letters, pp. 21-24, 1991.

[25] M. A. DeWit, Z. Wang, K. M. Atkins, K. Mequanint, and E. R. Gillies, "Syntheses, characterization, and functionalization of poly(ester amide)s with pendant amine functional groups," Journal of Polymer Science A, vol. 46, no. 19, pp. 6376-6392, 2008.

[26] D. K. Knight, E. R. Gillies, and K. Mequanint, "Strategies in functional poly(ester amide) syntheses to study human coronary artery smooth muscle cell interactions," Biomacromolecules, vol. 12, no. 7, pp. 2475-2487, 2011.

[27] G. Jokhadze, M. Machaidze, H. Panosyan, C. C. Chu, and R. Katsarava, "Synthesis and characterization of functional elastomeric poly(ester amide) co-polymers," Journal of Biomaterials Science, Polymer Edition, vol. 18, no. 4, pp. 411-438, 2007.

[28] V. Montserrat, L. Franco, and J. Puiggali, "Synthesis of poly (ester amide)s with lateral groups from a bulk polycondensation reaction with formation of sodium chloride salts," Journal of Polymer Science A, vol. 46, no. 2, pp. 661-667, 2008.

[29] Z. Guan, "Supramolecular design in biopolymers and biomimetic polymers for advanced mechanical properties," Polymer International, vol. 56, no. 4, pp. 467-473, 2007.

[30] D. A. Barrera, E. Zylstra, P. T. Lansbury, and P. T. Langer, "Synthesis and RGD peptide modification of a new biodegradable copolymer: poly(lactic acid-co-lysine)," Journal of the American Chemical Society, vol. 115, no. 23, pp. 11010-11011, 1993.

[31] M. Deng, J. Wu, C. A. Reinhart-King, and C. C. Chu, "Synthesis and characterization of biodegradable poly(ester amide)s with pendant amine functional groups and in vitro cellular response," Biomacromolecules, vol. 10, no. 11, pp. 3037-3047, 2009.

[32] K. Guo and C. C. Chu, "Synthesis of biodegradable aminoacid-based poly(ester amide)s and poly(ether ester amide)s with pendant functional groups," Journal of Applied Polymer Science, vol. 117, no. 6, pp. 3386-3394, 2010.

[33] K. Guo and C. C. Chu, "Biodegradable and injectable paclitaxel-loaded poly(ester amide)s microspheres: fabrication and characterization," Journal of Biomedical Materials Researchc B, vol. 89, no. 2, pp. 491-500, 2008.

[34] T. Ouchi, A. Hamada, and Y. Ohya, "Biodegradable microspheres having reactive groups prepared from L-lactic aciddepsipeptide copolymers," Macromolecular Chemistry and Physics, vol. 200, no. 2, pp. 436-441, 1999.

[35] S. H. Lee, I. Szinai, K. Carpenter et al., "In-vivo biocompatibility evaluation of stents coated with a new biodegradable elastomeric and functional polymer," Coronary Artery Disease, vol. 13, no. 4, pp. 237-241, 2002.

[36] Y. Huang, L. Wang, S. Li et al., "Stent-based tempamine delivery on neointimal formation in a porcine coronary model," Acute Cardiac Care, vol. 8, no. 4, pp. 210-216, 2006.

[37] K. M. Defife, K. Grako, G. Cruz-Aranda et al., "Poly(ester amide) co-polymers promote blood and tissue compatibility," Journal of Biomaterials Science, Polymer Edition, vol. 20, no. 11, pp. 1495-1511, 2009.

[38] D. Wu, X. Zhang, and C. C. Chu, "Synthesis, characterization and drug release from three-arm poly(epsilon-caprolactone) maleic acid/poly(ethylene glycol) diacrylate hydrogels," Journal of Biomaterials Science, Polymer Edition, vol. 14, no. 8, pp. 777-802, 2003.

[39] Y. D. Park, N. Tirelli, and J. A. Hubbell, "Photopolymerized hyaluronic acid-based hydrogels and interpenetrating networks," Biomaterials, vol. 24, no. 6, pp. 893-900, 2003.

[40] X. Pang and C. C. Chu, "Synthesis, characterization and biodegradation of poly(ester amide)s based hydrogels," Polymer, vol. 51, no. 18, pp. 4200-4210, 2010.

[41] D. Dai Yamanouchi, J. Wu, A. N. Lazar, K. C. Kent, C. C. Chu, and B. Liu, "Biodegradable arginine-based poly(ester-amide)s as non-viral gene delivery reagents," Biomaterials, vol. 29, no. 22, pp. 3269-3277, 2008.

[42] J. A. Horwitz, K. M. Shum, J. C. Bodle, M. Deng, C. C. Chu, and C. A. Reinhart-King, "Biological performance of biodegradable amino acid-based poly(ester amide)s: endothelial cell adhesion and inflammation in vitro," Journal of Biomedical Materials Research A, vol. 95, no. 2, pp. 371-380, 2010.

[43] P. Karimi, A. S. Rizkalla, and K. Mequanint, "Versatile biodegradable poly(ester amide)s derived from alpha-amino acids for vascular tissue engineering," Materials, vol. 3, no. 4, pp. 2346-2368, 2010.

[44] C. J. Bettinger, J. P. Bruggeman, J. T. Borenstein, and R. S. Langer, "Amino alcohol-based degradable poly(ester amide) elastomers," Biomaterials, vol. 29, no. 15, pp. 2315-2325, 2008.

[45] K. Breitenkamp and T. Emrick, "Novel polymer capsules from amphiphilic graft copolymers and cross-metathesis," Journal of the American Chemical Society, vol. 125, no. 40, pp. 1207012071, 2003.

[46] S. Verbrugghe, A. Laukkanen, V. Aseyev, H. Tenhu, F. M. Winnik, and F. E. Du Prez, "Light scattering and microcalorimetry studies on aqueous solutions of thermo-responsive PVCL-gPEO copolymers," Polymer, vol. 44, no. 22, pp. 6807-6814, 2003. 
[47] D. Tang, J. Lin, S. Lin, S. Zhang, T. Chen, and X. Tian, "Selfassembly of poly ( $\gamma$-benzyl L-glutamate)-graft(ethylene glycol) and its mixtures with poly ( $\gamma$-benzyl L-glutamate) homopolymer," Macromolecular Rapid Communications, vol. 25, no. 13, pp. 1241-1246, 2004.

[48] M. Shi and M. S. Shoichet, "Furan-functionalized co-polymers for targeted drug delivery: caracterization, self-assembly and drug encapsulation," Journal of Biomaterials Science, Polymer Edition, vol. 19, no. 9, pp. 1143-1157, 2008.

[49] R. K. Iha, B. A. van Horn, and K. L. Wooley, "Complex, degradable polyester materials via ketoxime ether-based functionalization: amphiphilic, multifunctional graft copolymers and their resulting solution-state aggregates," Journal of Polymer Science A, vol. 48, no. 16, pp. 3553-3563, 2010.

[50] J. M. Harris, N. E. Martin, and M. Modi, "Pegylation: a novel process for modifying pharmacokinetics," Clinical Pharmacokinetics, vol. 40, no. 7, pp. 539-551, 2001.

[51] J. M. Harris and S. Zalipsky, "Poly(ethylene glycol) chemistry and biological applications," in Proceedings of the American Chemical Society Symposium Series 680 (ACS '97), Amercan Chemical Society, Washington, DC, USA, 1997.

[52] R. B. Greenwald, C. D. Conover, and Y. H. Choe, "Poly(ethylene glycol) conjugated drugs and prodrugs: a comprehensive review," Critical Reviews in Therapeutic Drug, vol. 17, no. 2, pp. 101-161, 2000.

[53] M. L. Nucci, R. Shorr, and A. Abuchowski, "The therapeutic value of poly(ethylene glycol)-modified proteins," Advanced Drug Delivery Reviews, vol. 6, no. 2, pp. 133-151, 1991.

[54] B. H. Zimm and W. H. Stockmayer, "The dimensions of chain molecules containing branches and rings," Journal of Chemical Physics, vol. 17, no. 12, pp. 1301-1314, 1949.

[55] S. P. Perrault and W. C. W. Chan, "In vivo assembly of nanoparticle components to improve targeted cancer imaging," Proceedings of the National Academy of Sciences of the United States of America, vol. 107, no. 25, pp. 11194-11199, 2010.

[56] P. Greenspan, E. P. Mayer, and S. D. Fowler, "Nile red: a selective fluorescent stain for intracellular lipid droplets," Journal of Cell Biology, vol. 100, no. 3, pp. 965-973, 1985.

[57] M. M. G. Krishna, "Excited-state kinetics of the hydrophobic probe Nile red in membranes and micelles," Journal of Physical Chemistry A, vol. 103, no. 19, pp. 3589-3595, 1999.

[58] I. R. Freshney, Culture of Animal Cells: A Manual of Basic Technique, Wiley-Liss, New York, NY, USA, 4th edition, 2000.

[59] International Standard 10993-5 Biological Evaluation of Medical Devices-Tests for In vitro Cytotoxicity, 2009. 

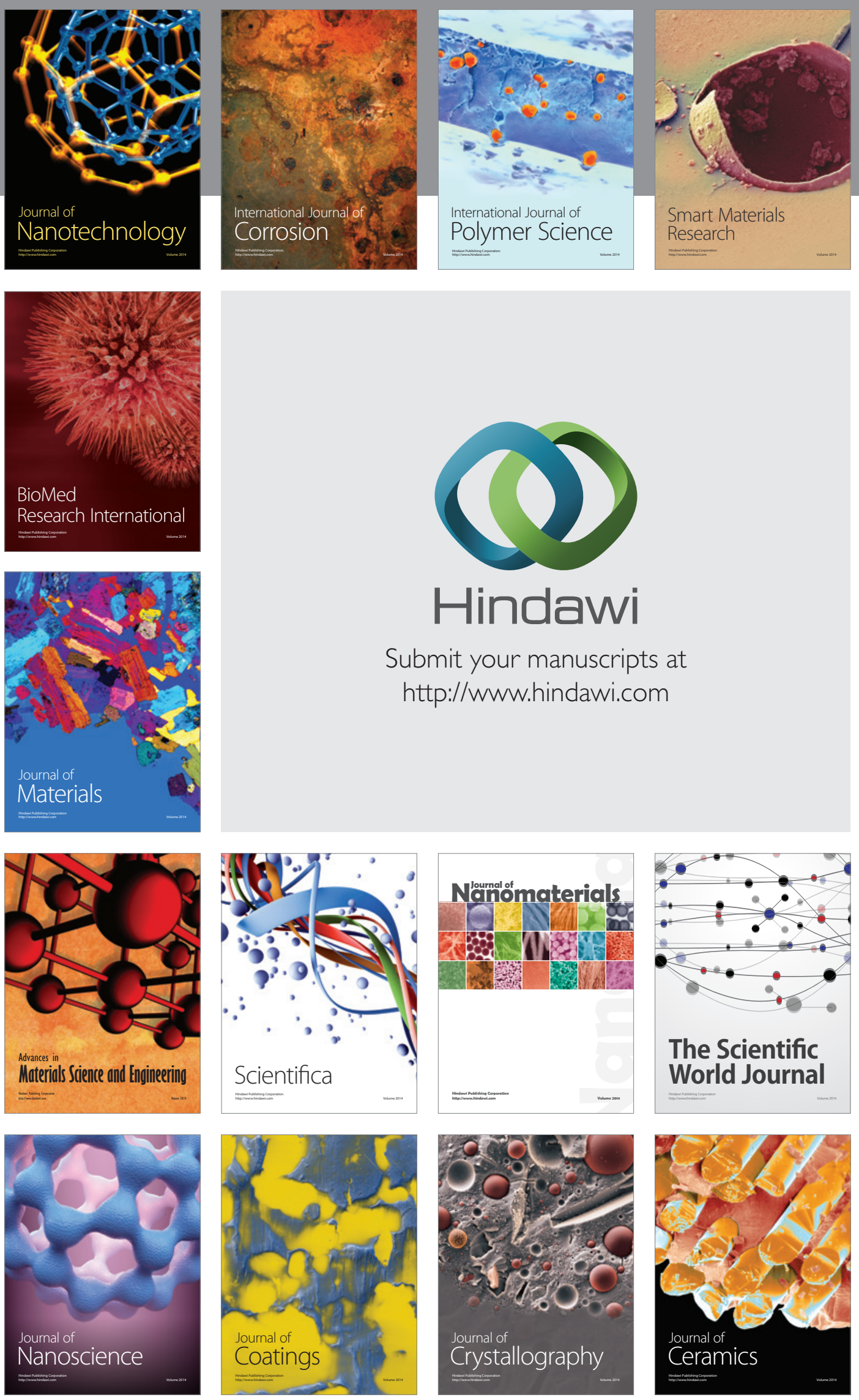

The Scientific World Journal

Submit your manuscripts at

http://www.hindawi.com

\section{World Journal}

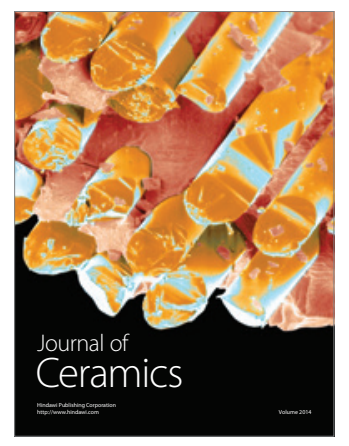

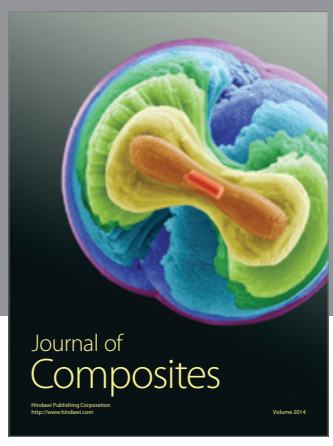
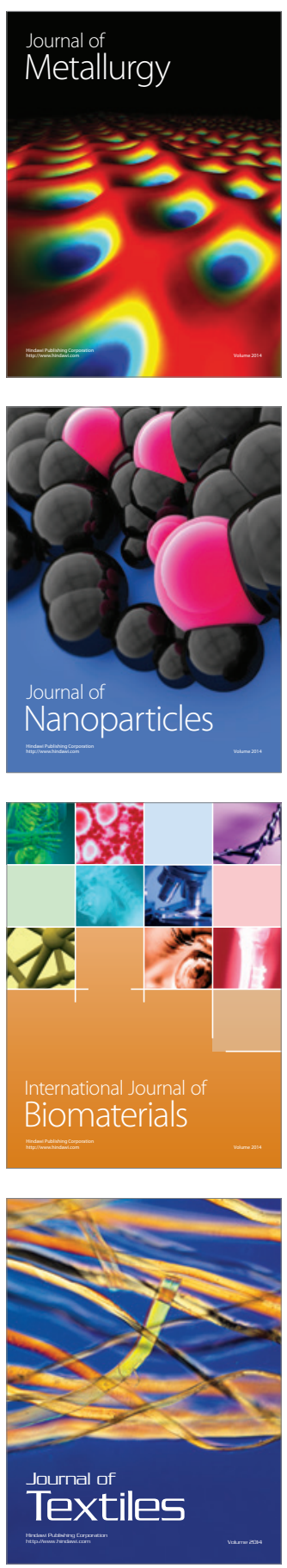